UDC 546.719:54-386

\author{
A. Slipkan ${ }^{a, b}$, N. Shtemenko ${ }^{a, b}$, R. Bray ${ }^{c}$, H. Obarska-Pempkowiak ${ }^{c}$, A. Shtemenko ${ }^{a}$
}

\title{
AGGREGATION PROPERTIES OF SOME ZIRCONIUM PHOSPHATE LOADED WITH DIRHENIUM(III) COMPLEXES
}

\author{
${ }^{a}$ Ukrainian State University of Chemical Technology, Dnipro, Ukraine \\ b National TU Dnipro Polytechnic, Dnipro, Ukraine \\ c Gdansk University of Technology, Gdansk, Poland
}

\begin{abstract}
One of the important areas of modern science is the selection of the right forms of drug delivery. Layered inorganic nanoparticles, such as zirconium phosphate, have proven themselves well in this area. The study of the properties of these systems and methods of their preparation makes it possible to determine a rational technology of their manufacture, storage conditions as well as suggest a possible mechanism of therapeutic action. The physical dimensions of the formed aggregates, morphology and structure are often the most influential factors for controlling the active surface area, reactivity, bioavailability and toxicity of nanoparticles. Aggregation properties of zirconium phosphate nanoparticles loaded with cluster rhenium(III) compounds with propionate ligands of different structure types (di-, tri- and tetra-carboxylates) and cisplatin were investigated by laser diffraction method in water. It was shown that the quantity and orientation of propionate ligands affect the aggregation properties of the investigated compounds. However, the presence of cisplatin in the composites reduced the aggregation abilities of the nanoparticles which indicate the formation of new complexes on their surfaces. After sonication, cisplatinrhenium compound composites had practically the same size-distribution curves. Our findings showed that the formation of different complexes with $\mathrm{ZrP}$ occurs on the surfaces depending from the structure of the rhenium substances.
\end{abstract}

Keywords: dirhenium(III) complex, cisplatine, zirconium phosphate; nanoparticle; sonication; aggregation properties.

DOI: $10.32434 / 0321-4095-2018-121-6-72-76$

\section{Introduction}

The selection of the right forms of drug delivery is an important area of modern science. Layered inorganic nanoparticles, such as zirconium phosphate, have proven themselves well in this area. The study of the properties of these systems and methods of their preparation allows determining a rational technology of their manufacture, storage conditions and suggesting a possible mechanism of therapeutic action. The physical dimensions of the formed aggregates, morphology and structure are often the most influential factors for controlling the active surface area, reactivity, bioavailability and toxicity of nanoparticles. In our previous publications [1-3], the methods of preparation and investigation of zirconium phosphate nanoparticles loaded with dirhenium(III) compounds of different structural types and ligands were elaborated. We have prepared the nanoparticles containing a dirhenium(III) compound and cisplatin in molar ratio of $4: 1$ according to the same procedure. Before characterization the obtained composites by some expensive methods, we investigated their size distributions by laser diffraction method to compare their aggregation properties in water. Molar ratio of dirhenium(III) compound to cisplatin of $4: 1$ was taken due to the earlier shown anticancer activity of liposomes with the same content $[4,5]$. Besides, the aggregation properties of nanoparticles in water have additional significance to predict their fate in environment and living organisms [6-10].

\section{Materials and methods}

The following compounds were used for preparation of nanoparticles: trans- $\mathrm{Re}_{2}\left(\mathrm{C}_{2} \mathrm{H}_{5} \mathrm{COO}\right)_{2} \mathrm{Cl}_{4}$ (trans-tetrachlorodi- $\mu$-propionatodirhenium(III)), $\mathrm{Re}_{2}\left[\left(\mathrm{C}_{2} \mathrm{H}_{5} \mathrm{COO}\right)_{3} \mathrm{Cl}_{3}\right]$ (trichlorotri- $\mu$-propionato-

(C) A. Slipkan, N. Shtemenko, R. Bray, H. Obarska-Pempkowiak, A. Shtemenko, 2018 
dirhenium(III)), $\mathrm{Re}_{2}\left[\left(\mathrm{C}_{2} \mathrm{H}_{5} \mathrm{COO}\right)_{4} \mathrm{Cl}_{2}\right]$ (dichlorotetra$\mu$ - propionatodirhenium(III)), cis-[ $\left.\mathrm{Pt}\left(\mathrm{NH}_{3}\right)_{2} \mathrm{Cl}_{2}\right]$ (cisdiamminedichloroplatinum(II), i.e. cisplatin), and $\mathrm{Zr}\left(\mathrm{HPO}_{4}\right)_{2}$ (zirconium hydrophosphate, $\mathrm{ZrP}$ ); they were synthesized according to procedure described elsewhere [11-15].

Encapsulation procedure was performed according to refs. [1-3]. In short, $\mathrm{ZrP}$ or $\mathrm{ZrP}$ and plus cisplatin were added to the $5 \cdot 10^{-4} \mathrm{M}$ solution of the dirhenium(III) compound in isopropanol in quantities according to the following molar ratios: $\mathrm{ZrP}$ :rhenium compound of $5: 1$, or $\mathrm{ZrP}$ :rhenium compound:cisplatin of 20:4:1. After boiling during 5 days with spectral control, the obtained nanocomposites were washed by solvent and dried on the fresh air.

Following nanocomposites were obtained according to this procedure: $\mathrm{ZrP} /$ trans- $\mathrm{Re}_{2}\left(\mathrm{C}_{2} \mathrm{H}_{5} \mathrm{COO}\right)_{2} \mathrm{Cl}_{4}$ 5:1 (I), ZrP/trans- $\mathrm{Re}_{2}\left(\mathrm{C}_{2} \mathrm{H}_{5} \mathrm{COO}\right)_{2} \mathrm{Cl}_{4} /$ cisPt 20:4:1 (Ia), $\mathrm{ZrP} / \mathrm{Re}_{2}\left[\left(\mathrm{C}_{2} \mathrm{H}_{5} \mathrm{COO}\right)_{3} \mathrm{Cl}_{3}\right] \quad 5: 1 \quad$ (II), $\mathrm{ZrP} / \mathrm{Re}_{2}\left[\left(\mathrm{C}_{2} \mathrm{H}_{5} \mathrm{COO}\right)_{3} \mathrm{Cl}_{3}\right] /$ cisPt 20:4:1 (IIa), $\mathrm{ZrP} / \mathrm{Re}_{2}\left[\left(\mathrm{C}_{2} \mathrm{H}_{5} \mathrm{COO}\right)_{4} \mathrm{Cl}_{2}\right] \quad 5: 1$ (III), and $\mathrm{ZrP} / \mathrm{Re}_{2}\left[\left(\mathrm{C}_{2} \mathrm{H}_{5} \mathrm{COO}\right)_{4} \mathrm{Cl}_{2}\right] /$ cisPt 20:4:1 (IIIa).

To measure the sizes of particles, the laser diffraction particle size analyzer Mastersizer Hydro 2000MU (Malvern Instruments Ltd.) was used.

Equimolar quantities of I-III, Ia-IIIa in the range of 5-7 mg were dispersed in $50 \mathrm{~mL}$ of water and rigorously mixed by magnetic stirrer during $5 \mathrm{~min}$. The resulting suspension had a turbidity of 1.8 to
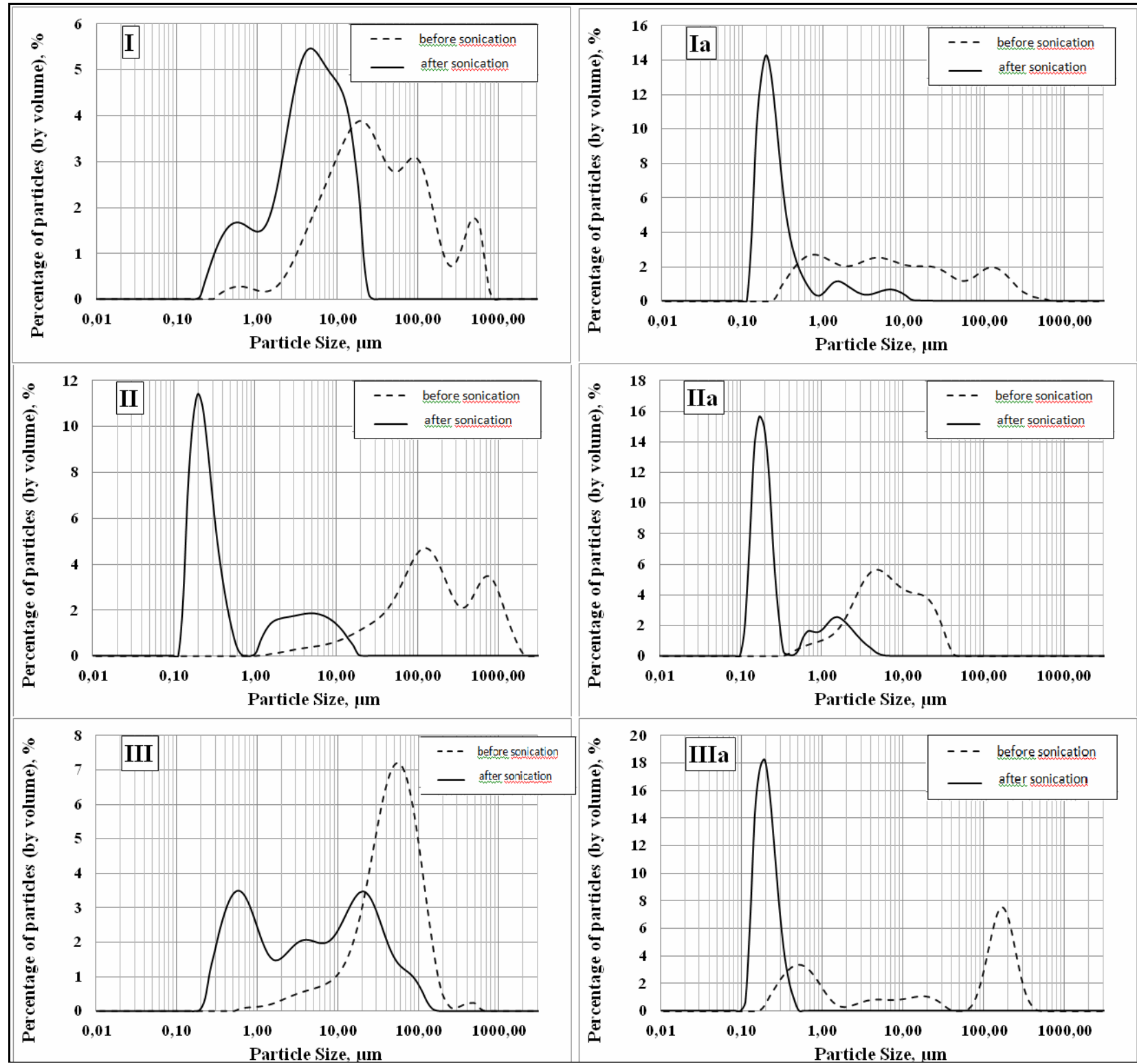

Size distribution of nanoparticles in I-III and Ia-IIIa nanocomposites before and after sonication 
$5.1 \%$. The suspension thus prepared was pumped by means of a peristaltic pump to the measuring cell of the particle size analyzer and returned to the measuring flask. After that, the laser diffraction method with the use of particle size analyzer was accomplished using Master sizer HYDRO 2000MU Malvern Instruments (Malvern Panalytical).

The second measurement of nanoparticles sizes was accomplished after 2 minutes of ultra-sonication. Each measurement was repeated 10-12 times and the average curves of nanoparticles sizes distribution were plotted.

In addition to the particle size distribution, such values as d10, d50, and $\mathrm{d} 90$ were calculated and the largest and smallest particles observed during the measurement were determined. The characteristic values (d10, d50, and d90) are defined as follows: d10 - particles of this and smaller diameters constituting $10 \%$ of the total volume of all particles in the sample, d50 (average particle size) - particles of this and smaller diameters constituting $50 \%$ of the total volume of all particles in the sample, and d90 - particles of this and smaller diameters constituting $90 \%$ of the total volume of all particles in the sample.

Any time when the term «dimension» or «size» of the particles is mentioned in this study, it means the equivalent diameter of the particles, which value is the average of the measurement interval within the range of approximately $\pm 7 \%$ of a given value.

\section{Results and discussion}

Figure and Table show the size distribution curves of I-III, Ia-IIIa nanocomposites.

It is well-known that a high ratio of surface area to volume of nanoparticles leads to highly reactive and instable colloid as compared with bulk substrates. Thus, there is no surprise that simple procedure of mixing of I-III and Ia-IIIa in water led to the formation of aggregates with sizes of $1000 \mu \mathrm{m}$ and larger (dashed and solid lines in Figure, accordingly).

Size-distribution curves before sonication (dash lines) have no strict relation to the structure of the investigated substances that may be an effect of nanocomposites storing and water molecules entrapping.

The sonication procedure breaks aggregates and shifts the size distribution curves to smaller particles, however of different distribution. In the preparations without cisplatin, this shift led to the formation of smaller particles.

The smallest particles were achieved for the composite II $(\sim 0.5 \mu \mathrm{m})$ while the largest ones were observed for the composite I $(\sim 5 \mu \mathrm{m})$. It is likely that the aggregation abilities depend on the structure of the dirhenium(III) compounds, in particular on hydrophobic interactions of the propionate ligands, abundant in $\operatorname{Re}_{2}\left[\left(\mathrm{C}_{2} \mathrm{H}_{5} \mathrm{COO}\right)_{4} \mathrm{Cl}_{2}\right]$, where there are 4 hydrophobic ligands, and on the quantity of chlorine atoms in the molecule, that is the largest for trans- $\mathrm{Re}_{2}\left(\mathrm{C}_{2} \mathrm{H}_{5} \mathrm{COO}\right)_{4} \mathrm{Cl}_{2}$ amounting to four atoms of chlorine. The chlorine atoms are the most electronegative atoms in the molecules of the investigated dirhenium(III) compounds and may be responsible for electrostatic interactions between nanoparticles, while hydrophobic interactions may be more responsible for aggregation of the III composite. The symmetry of the molecules structure may also impact on the aggregation abilities of the complexes. In any case, the structure of the encapsulated substances influences the aggregation properties of the composites.

Encapsulation of cisplatin changed the size distribution of the composites in a large extend after sonication procedures. It is interesting that these cisplatin-rhenium composites after sonication exhibited practically the same size-distribution curves. Most particles were in the range of about $0.1-0.5 \mu \mathrm{m}$ and the average particle size (d50) was about $0.2-0.25 \mu \mathrm{m}$ (Table).

According to colloid science and aggregation theory, the aggregation of nanoparticles occurs when physical processes bring particle surfaces in contact with each other [7]. When contact occurs, it can result in attachment or repulsion depending on the surface properties (charge, moieties, etc.). The obtained results allow us to conclude that the formation of different complexes with $\mathrm{ZrP}$ took place

Characteristic values of nanoparticles size (I-III, Ia-IIIa) before and after sonication

\begin{tabular}{c|c|c|c|c|c|c|c|c|c|c}
\hline \multirow{2}{*}{ Composite } & \multicolumn{5}{|c|}{ before sonication $(\mu \mathrm{m})$} & \multicolumn{5}{c}{ after sonication $(\mu \mathrm{m})$} \\
\cline { 2 - 13 } & $\min$ & $\max$ & $\mathrm{d} 10$ & $\mathrm{~d} 50$ & $\mathrm{~d} 90$ & $\min$ & $\max$ & $\mathrm{d} 10$ & $\mathrm{~d} 50$ & $\mathrm{~d} 90$ \\
\hline I & 0.275 & 778.1 & 4.69 & 26.4 & 226.2 & 0.182 & 24.6 & 0.60 & 4.10 & 12.4 \\
\hline Ia & 0.209 & 677.7 & 0.57 & 5.79 & 119.8 & 0.120 & 28.2 & 0.14 & 0.22 & 1.2 \\
\hline II & 0.724 & 2046.6 & 20.56 & 135.6 & 809.8 & 0.120 & 21.4 & 0.15 & 0.25 & 5.5 \\
\hline IIa & 0.316 & 42.8 & 1.63 & 5.7 & 20.1 & 0.105 & 6.18 & 0.13 & 0.2 & 1.6 \\
\hline III & 0.55 & 677.7 & 10.81 & 43.8 & 105.6 & 0.182 & 170.2 & 0.42 & 4.7 & 37.1 \\
\hline IIIa & 0.158 & 513.1 & 0.37 & 61.0 & 213.9 & 0.105 & 0.590 & 0.13 & 0.2 & 0.3 \\
\hline
\end{tabular}


on the surfaces of I-III, depending on the structure of the rhenium substrates. However, the formation of the complexes similar in polarity or even structure may occur in the case of Ia-IIIa.

\section{Conclusions}

Taking into account the formation of the complex between a rhenium compound and cisplatin inside in liposome [6] that had been confirmed by spectral methods, the following structure of a new complex on the surface of Ia-IIIa is proposed:

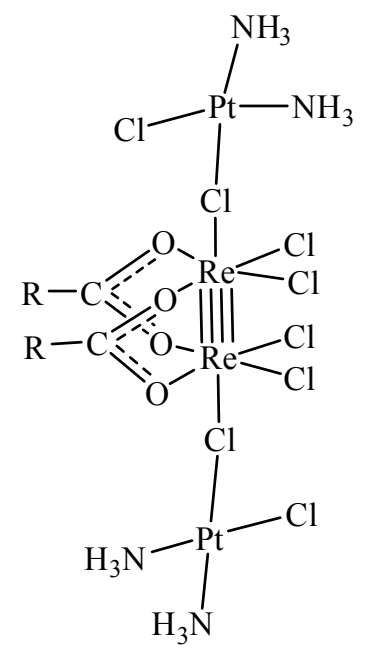

Acknowledgments

The work was accomplished with the promotion of the Erasmus+exchange program during visit of Prof. Dr. Shtemenko N. to Gdansk University of Technology in 2018.

\section{REFERENCES}

1. Шаруваті наночастки цирконій гідрофосфату як форма упаковки для trans- $\mathrm{Re}_{2}(\mathrm{RCOO})_{2} \mathrm{Cl}_{4}$ / Сліпкань А.В., Китова Д.Є., Штеменко О.В. // Вопр. химии и хим. технологии. - 2016. - № 3. - С.21-25.

2. Сліпкань А.В., Китова Д.С., Штеменко О.В. Наночастки цирконій гідрофосфату як форма упаковки для дигалогенотетранал. - 2017. - Т.83. - № 7-8. - С.35-41.

3. Сліпкань А.В., Китова Д.С., Штеменко О.В. Наночастки цирконій гідрофосфату, навантажені трихлоротрим-карбоксилатами диренію(III) // Вопр. химии и хим. технологии. - 2018. - № 2. - С.39-45.

4. Synthesis, X-ray structure, interactions with DNA, remarkable in vivo tumor growth suppression and nephroprotective activity of cis-tetrachloro-dipivalato dirhenium(III) / Shtemenko N.I., Chifotides H.T., Domasevich K.V., et al. // J. Inorg.
Biochem. - 2013. - Vol.129. - P.127-134.

5. Liposomes loaded with a dirhenium compound and cisplatin: preparation, properties and improved in vivo anticancer activity / Li Z., Shtemenko N.I., Yegorova D.Y., et al. // J. Liposome Res. - 2015. - Vol.25. - P.78-87.

6. Fabrication of aggregation-induced emission based fluorescent nanoparticles and their biological imaging application: recent progress and perspectives / Yang B., Zhang X., Zhang X., et al. // Mater. Today. - 2016. - Vol.19. - P.284-291.

7. Rosicka D., Sembera J. Changes in the nanoparticle aggregation rate due to the additional effect of electrostatic and magnetic forces on mass transport coefficients // Nanoscale Res. Lett. - 2013. - Vol.8. - P.20-29.

8. Hotze E.M., Phenrat T., Lowry G.V. Nanoparticle aggregation: challenges to understanding transport and reactivity in the environment // J. Environ. Qual. - 2010. - Vol.39. P.1909-1924.

9. Stochastic probability modeling to predict the environmental stability of nanoparticles in aqueous suspension / Mackay C.E., Johns M., Salatas J.H., et al. // Integr. Environ. Assess. Manage. - 2006. - Vol.2. - No. 3. - P.293-298.

10. Alzoubi F.Y., Abu Bidier S.A. Characterization and aggregation of silver nanoparticles dispersed in an aqueous solution // Chin. J. Phys. - 2013. - Vol.51. - No. 2. - P.378-387.

11. Штеменко А.В., Котельникова А.С. Образование биядерных галогенокарбоксилатных соединений рения с четверной связью металл-металл // Извест. АН СССР. Сер. Химическая. - 1980. - С.2630-2632.

12. Cotton F.A., Gage L.D., Rice C.E. Some new types of quadruply bonded dirhenium compounds containing bridging carboxylato groups // Inorg. Chem. - 1979. - Vol.18. - No. 4. - P.1138-1142.

13. Synthesis and $\mathrm{X}$-ray crystal structure of the dirhenium complex $\mathrm{Re}_{2}\left(\mathrm{i}-\mathrm{C}_{3} \mathrm{H}_{7} \mathrm{COO}\right)_{4} \mathrm{Cl}_{2}$ and its interactions with the DNA purine nucleobases / Shtemenko A.V., Chifotides H.T., Yegorova D.E., et al. // J. Inorg. Biochem. - 2015. - Vol.153. - P.114120 .

14. Брауэр Г. Руководство по неорганическому синтезу. - М. :Мир, 1995. - Т.5. - 1825 с.

15. Marti A.A., Colon J.L. Direct ion exchange of tris(2,2'bipyridine) ruthenium(II) into an $\alpha$-zirconium phosphate framework // Inorg. Chem. - 2003. - Vol.42. - P.2830-2832.

Received 05.10.2018

\section{АГРЕГАЦІЙНІ ВЛАСТИВОСТІ ДЕЯКИХ ФОСФАТІВ ЦИРКОНІЮ, НАВАНТАЖЕНИХ КОМПЛЕКСАМИ ДИРЕНІЮ(III)}

А.В. Сліпкань, Н.І. Штеменко, Р. Брей, Х. ОбарскаПемпковак, О.В. Штеменко

Однією з важливих галузей сучасної науки став вибір правильних форм доставки ліків. Шаруваті неорганічні наночастинки, такі як фосфат цирконію, добре зарекомендували себе в цій галузі. Вивчення властивостей цих систем і методів 
їx підготовки дозволяє визначити раціональну технологію їх виробництва, умов зберігання, а також запропонувати можливий механізм терапевтичної дії. Фізичні розміри сформованих агрегатів, морфологія і структура часто є найбільш впливовими факторами для контролю активної площі поверхні, реакційної здатності, біодоступності і токсичності наночастинок. Агрегаційні властивості наночастинок цирконій фосфату, навантажені кластерними сполуками ренію(III) з пропіонатними лігандами різних структурних типів (ди-, тритетракарбоксилати) $і$ ицсплатином, були досліджені методом світлорозсіювання в воді. Показано, що кількість $і$ орієнтація пропіонатних лігандів впливають на агрегаційні властивості досліджсвваних сполук. Але наявність иисплатину в композитах зменшувало агрегаційні здатності наночасток, які свідчать про формування нових комплексів на їх поверхнях. Після оброблення ультразвуком композитів цисплатин-ренієва сполука мали практично однакові криві розподілу за розмірами. Отримані нами результати дозволяють зробити висновок про те, що в залежності від структури ренієвої сполуки на поверхні відбувається утворення різних комплексів з $\mathrm{ZrP}$.

Ключові слова: комплекси диренію(III), цисплатин, фосфат цирконію, наночастинки, ультразвук, агрегаційні властивості.

\section{AGGREGATION PROPERTIES OF SOME ZIRCONIUM PHOSPHATE LOADED WITH DIRHENIUM(III) COMPLEXES}

A. Slipkan ${ }^{a, b}$, N. Shtemenko ${ }^{a, b}$, R. Bray ${ }^{c}$,

H. Obarska-Pempkowiak ${ }^{c}$, A. Shtemenko ${ }^{a}$

a Ukrainian State University of Chemical Technology, Dnipro, Ukraine

b National TU Dnipro Polytechnic, Dnipro, Ukraine

c Gdansk University of Technology, Gdansk, Poland

One of the important areas of modern science is the selection of the right forms of drug delivery. Layered inorganic nanoparticles, such as zirconium phosphate, have proven themselves well in this area. The study of the properties of these systems and methods of their preparation makes it possible to determine a rational technology of their manufacture, storage conditions as well as suggest a possible mechanism of therapeutic action. The physical dimensions of the formed aggregates, morphology and structure are often the most influential factors for controlling the active surface area, reactivity, bioavailability and toxicity of nanoparticles. Aggregation properties of zirconium phosphate nanoparticles loaded with cluster rhenium(III) compounds with propionate ligands of different structure types (di-, tri-and tetra-carboxylates) and cisplatin were investigated by laser diffraction method in water. It was shown that the quantity and orientation of propionate ligands affect the aggregation properties of the investigated compounds. However, the presence of cisplatin in the composites reduced the aggregation abilities of the nanoparticles which indicate the formation of new complexes on their surfaces. After sonication, cisplatin-rhenium compound composites had practically the same size-distribution curves. Our findings showed that the formation of different complexes with $\mathrm{ZrP}$ occurs on the surfaces depending from the structure of the rhenium substances.

Keywords: dirhenium(III) complex; cisplatine; zirconium phosphate; nanoparticle; sonication; aggregation properties.

\section{REFERENCES}

1. Slipkan A.V., Kytova D.E., Shtemenko A.V. Sharuvati nanochastky tsyrkoniyu gidrophosphatu yak forma upakovky dl'ya trans- $\mathrm{Re}_{2}(\mathrm{RCOO})_{2} \mathrm{Cl}_{4}$ [Layered zirconium phosphate nanoparticles as a form of packaging for the trans$\left.\mathrm{Re}_{2}(\mathrm{RCOO})_{2} \mathrm{Cl}_{4}\right]$. Voprosy Khimii i Khimicheskoi Tekhnologii, 2016, no. 3, pp. 21-25. (in Ukrainian).

2. Slipkan A.V., Kytova D.E., Shtemenko A.V. Nanochastki tsirkonii gidrofosfatu yak forma upakovky dl'ya digalogenotetra$\mu$-carboxilativ direniyu(III) [Zirconium phosphate nanoparticles as a form of packaging for dihalogenotere- $\mu$-carboxylates of dirhenium(III)]. Ukrainian Chemistry Journal, 2017, vol. 83, no. 7-8, pp. 35-41. (in Ukrainian).

3. Slipkan A.V., Kytova D.E., Shtemenko A.V. Nanochastynky tsyrkonii gidrofofsfatu, navantazheni trykhlorotry$\mu$-karboksylatamy dyreniyu(III) [Nanoparticles of zirconium phosphate loaded with trichlorotri- $\mu$-carboxylates of dirhenium(III)]. Voprosy Khimii i Khimicheskoi Tekhnologii, 2018, no. 2, pp. 39-45. (in Ukrainian).

4. Shtemenko N.I., Chifotides H.T., Domasevitch K.V., Golichenko A.A., Babiy S.A., Li Z., Paramonova K.V., Shtemenko A.V., Dunbar K.R. Synthesis, X-ray structure, interactions with DNA, remarkable in vivo tumor growth suppression and nephroprotective activity of cis-tetrachloro-dipivalato dirhenium(III). Journal of Inorganic Biochemistry, 2013, vol. 129, pp. 127-134.

5. Li Z., Shtemenko N.I., Yegorova D.Y., Babiy S.O., Brown A.J., Yang T., Shtemenko A.V., Dunbar K.R. Liposomes loaded with a dirhenium compound and cisplatin: preparation, properties and improved in vivo anticancer activity. Journal of Liposome Research, 2015, vol. 25, pp. 78-87.

6. Yang B., Zhang X., Zhang X., Huang Z., Wei Y., Tao L. Fabrication of aggregation-induced emission based fluorescent nanoparticles and their biological imaging application: recent progress and perspectives. Materials Today, 2016, vol. 19, pp. 284-291.

7. Rosicka D., Sembera J. Changes in the nanoparticle aggregation rate due to the additional effect of electrostatic and magnetic forces on mass transport coefficients. Nanoscale Research Letters, 2013, vol. 8, pp. 20.

8. Hotze E.M., Phenrat T., Lowry G.V. Nanoparticle aggregation: challenges to understanding transport and reactivity in the environment. Journal of Environmental Quality, 2010, vol. 39, pp. 1909-1924.

9. Mackay C.E., Johns M., Salatas J.H., Bessinger B., Perri M. Stochastic probability modeling to predict the environmental stability of nanoparticles in aqueous suspension. Integrated Environmental Assessment and Management, 2006, vol. 2, pp. 293-298.

10. Alzoubi F.Y., Abu Bidier S.A. Characterization and aggregation of silver nanoparticles dispersed in an aqueous solution. Chinese Journal of Physics, 2013, vol. 51, no. 2, pp. 378-387.

11. Shtemenko A.V., Kotelnikova A.S. The formation of binuclear halocarboxylate compounds of rhenium with the metalmetal quadruple bond. Izvestiya Akademii Nauk SSSR, Seriya Khimicheskaya, 1980, pp. 2630-2632. (in Russian).

12. Cotton F.A., Gage L.D., Rice C.E. Some new types of quadruply bonded dirhenium compounds containing bridging carboxylato groups. Inorganic Chemistry, 1979, vol. 18, pp. 11381142.

13. Shtemenko A.V., Chifotides H.T., Yegorova D.E., Shtemenko N.I., Dunbar K.R. Synthesis and X-ray crystal structure of the dirhenium complex $\mathrm{Re}_{2}\left(\mathrm{i}-\mathrm{C}_{3} \mathrm{H}_{7} \mathrm{COO}\right)_{4} \mathrm{Cl}_{2}$ and its interactions with the DNA purine nucleobases. Journal of Inorganic Biochemistry, 2015, vol. 153, pp. 114-120.

14. Brauer G., Guide to inorganic synthesis. Mir, Moscow, 1995, vol. 5. 1825 p. (in Russian).

15. Marti A.A., Colon J.L. Direction exchange of tris (2, 2'-bipyridine) ruthenium (II) into an $\alpha$-zirconium phosphate framework. Inorganic Chemistry, 2003, vol. 42, pp. 2830-2832. 